\title{
Model endophenotype for bipolar disorder: Qualitative Analyse, etiological factors and research areas
}

\author{
MODELO DE ENDOFENÓTIPO DO TRANSTORNO BIPOLAR: ANÁLISE QUALITATIVA, \\ FATORES ETIOLÓGICOS E ÂMBITOS DE INVESTIGAÇÃO ABORDADOS
}

\author{
MODELO ENDOFENOTIPO DE TRASTORNO BIPOLAR: ANÁLISIS CUALITATIVO, \\ FACTORES ETIOLÓGICOS Y LAS ÁREAS PARA LAS CUALES LA INVESTIGACIÓN
}

\author{
Naraiana de Oliveira Tavares ${ }^{1}$, Fernando da Silva Neves², Leandro Fernandes Malloy-Diniz ${ }^{3}$
}

\begin{abstract}
The aim of this study is to present an updated view of the writings on the endophenotype model for bipolar disorder using analytical methodologies. A review and analysis of networks was performed through descriptors and keywords that characterize the composition of the endophenotype model as a model of health. Information was collected from between 1992 and 2014, and the main thematic areas covered in the articles were identified. We discuss the results and question their cohesion, emphasizing the need to strengthen and identify the points of connection between etiological factors and characteristics that make up the model of endophenotypes for bipolar disorder.
\end{abstract}

\section{RESUMO}

O objetivo do presente estudo é o de apresentar uma visão atualizada sobre a produção bibliográfica do modelo de endofenótipo para o transtorno bipolar, recorrendo às metodologias analíticas. Foi realizada para tal uma revisão da literatura e uma análise de redes por meio de descritores e palavras-chaves, que caracterizam a composição do modelo de endofenótipo como um modelo de saúde. O período de recoIha das informações ocorreu entre os anos de 1992-2014, identificando nos principais artigos os âmbitos temáticos abordados. Discutem-se os resultados obtidos para a consolidação do modelo de endofenótipos, questionando a coesão e ressaltando a necessidade de reforçar e identificar os pontos de ligação entre os fatores etiológicos e as características que compõe o modelo de endofenótipos para o transtorno bipolar.

\section{DESCRITORES \\ Endofenótipos \\ Transtorno bipolar \\ Modelos de saúde \\ Análise qualitativa}

\section{RESUMEN}

El objetivo de este trabajo es presentar una visión actualizada de los escritos del modelo endofenotipo para el trastorno bipolar, el uso de las metodologías analíticas. Se realizó una revisión de este tipo de literatura y un análisis de las redes a través de descriptores y palabras clave que caracterizan la composición del modelo endofenotipo como modelo de salud. El momento de la recolección de la información se produjo entre los años 1992-2014, la identificación de las principales áreas temáticas incluidas en los artículos. Se discuten los resultados para la consolidación del modelo de endofenotipos, cuestionando la cohesión y haciendo hincapié en la necesidad de fortalecer e identificar los puntos de conexión entre los factores etiológicos y características que conforman el modelo de endofenotipos para el trastorno bipolar.

\section{DESCRIPTORES \\ Endofenotipo \\ Transtorno bipolar mood \\ Modelo de salud \\ Análisis analíticas}

${ }^{1}$ Professor of Psychology, School of Education, Federal University of Goiás and Doctoral student of the Post Graduate Program in Neurosciences at the Federal University of Minas Gerais, Belo Horizonte, Brazil. 2Professor of Mental Health Department and Psychiatry, Federal University of Minas Gerais, Belo Horizonte, Brazil. ${ }^{3}$ Professor of Mental Health Department and Psychiatry, Federal University of Minas Gerais,Belo Horizonte, Brazil. 


\section{INTRODUCTION}

Bipolar Disorder (BD) is one of the most studied psychiatric disorders in mental health literature. Its nature involves various concepts of health areas, models of prevention, treatment, and rehabilitation. The model of the World Health Organization aggregates the biological, psychological, and social spheres in various aspects of research. The endophenotype model, a new psychiatric model, involves searching for biological and behavioral neuroscience for the origin patterns of psychiatric disorders.

The endophenotype model is a multi-causal model proposed in of 1973. The model emphasizes the genetic factors or genetic vulnerability as determinants of major environmental changes ${ }^{(1)}$. The concept has gained strength and direction since the 90s. The aim of this work is to present an updated view of the research on the endophenotypes of bipolar disorder using analytical methodologies with scientific literature. Through examining the etiology, signs, and symptoms, we sought to identify how academia aggregates the factors.

One of the most widely accepted theories explains that the causal models of bipolar disorder are based on the first modification by a triggering condition that occurs due to stress, which would disrupt the environment and neuronal circuitry ${ }^{(2)}$. This change would be systematized and reach three major pathways (serotonergic, noradrenergic, and dopaminergic), and then affect the cycles of sleep and wakefulness. Producing changes in circadian cycles and the functioning of neurons would result in the onset of bipolar disorder.

\section{Genetic vulnerability and risk factors}

The factor that best describes the etiology of mood disorders appears to be genetics. The first association between patients and first-degree relatives showing a correlation between symptomatology and genetic variables has been observed for over a century ${ }^{(3)}$. Thus, it is assumed that the risk of developing bipolar spectrum disorder could be $9 \%$, and family members would have a nearly 10 -fold increased risk of developing the disease than the general population ${ }^{(4)}$. As in other psychiatric disorders known for their influences and genetic bases, the inheritance pattern of bipolar disorder likely involves a complex interaction of several genes. Researchers have proposed possible chromosomal differences on chromosomes $2,4,5,6,8$, $9,10,12,13,14,15,18,21,22$, and the $X$ chromosome in people with bipolar disorder. Therefore, there are several candidate genes for the development of pathology. It should be noted that the model is multifactorial, with environmental and individual factors contributing to the onset of the disease. The effects of each factor are small and cumulative, and since there are combined effects, the factors could have some critical value, perhaps caused by signaling cascades that make the disorder manifest ${ }^{(5,6)}$.

\section{Stress in bipolar disorder}

Stress is defined as an event that involves changes of any nature, whether good, bad, drastic, or sudden. The endophenotype model considers etiological causes for the bipolar spectrum, and stress would be the starting point for developing the disease ${ }^{(7)}$. By examining the psychosocial aspects such as the impact on quality of life, the time in which the subject was exposed to a stressful environment, and the symptoms and manifestations of the disease, one study recently revealed the association between traumatic life events and the highest levels of basal cortisol $^{(8)}$.

Increasing evidence suggests that BD is accompanied by structural changes in the brain that may be mediated by interactions between hypercortisol and glutamate neurotoxicity. This mechanism is induced by stress and reduces neurotrophic factors and neurogenesis ${ }^{(9)}$. It is assumed that the environmental stress factors trigger the development cascade of BD.

\section{Neuroscience of bipolar mood disorder}

Analyses with images of patients with bipolar disorder (BD) led to preliminary conclusions distinguishing two areas that change in the paralimbic system and the prefrontal cortex, including the amygdala. The prefrontal areas are significant in cognitive function, especially executive functions, which may explain behavioral and neuropsychological changes ${ }^{(10)}$. Another specific difference observed in subjects affected by BD could be described by way of resonances, showing significant loss of asymmetry of the left/right caudate nucleus and in the right anterior frontal region. Changes in the structure of the cerebellum are still being investigated, including ventricular asymmetry. The amygdala is one of many small structures deep inside the brain which are called basal ganglia. These structures are implicated in automatic movements and behaviors that are important in maintaining the sleep-wake cycle ${ }^{(11)}$.

\section{Circadian rhythms}

The changes in people with bipolar disorder can suggest specific errors in the regulation of the sleep/waking. Many involve the body's internal clock, which controls the phenomenon known as circadian rhythms. These are the regular rhythmic changes of waking and sleeping, decreased activity levels, and the sensations of hunger, thirst, and satisfaction. The chemical and biological clock that governs these rhythms is located in a part of the hypothalamus called the suprachiasmatic nucleus gland. The rhythms are based on the standard light-dark cycles and are set slowly in rhythm with the seasons. An important finding in the literature is that people with bipolar disorder seem to have more difficulty in regulating this system ${ }^{(12)}$.

The regulation of serotonin affects mood and appetite. In people with bipolar disorder, serotonin and other neurotransmitters may be issued in disproportionate amounts 
(serotonin hypothesis). Noradrenergic and dopaminergic hypotheses use the interaction models in cascade, such that the variation of the serotonin would cause a reduction in noradrenergic and dopaminergic activities. All these biochemical mechanisms can be directly linked to $\mathrm{BD}^{(13)}$.

\section{Endophenotype of bipolar disorder}

The first description of the endophenotype concept in psychiatric literature was revisited 20 years later thanks to the development of laboratory techniques ${ }^{(1)}$. The genome project has made led to review of the endophenotype concept. Today, there is a whole area called the biology of molecular genetics and molecular medicine, which studies the expression of endophenotypes ${ }^{(14)}$.

Another reason with greater importance in psychiatry and BD is the gap in the causal chain between genes and distal disease ${ }^{(14)}$ which casts doubt on the etiology. There are two additional conditions necessary to meet the criteria of an endophenotype: (a) the endophenotype should be an independent state and demonstrable in patients without symptoms; and (b) endophenotypes should be more frequent in affected relatives than in relatives of patients compared with the general population $^{(15)}$. The main difference between the concepts of exophenotype and endophenotype is that the first gene expression could be seen directly in the exophenotype. The endophenotype involves "internal phenotypes," which may not be visible to the naked eye (i.e. it relies on inferences). The endophenotype concept originally arose in evolutionary biology in an article published in 1966 , which proposed that the differences in biochemical and microscopic insects would be "internal phenotypes," which cannot be seen with the naked eye, requiring the use of some instruments to be measured. With the objective of defining the number of genes involved in endophenotype variations that determine the whole phenomenon of a psychiatric disorder, one realizes the description of elementary phenomena (versus behavioral macros found in the DSM-IV), which may not be able to delimit the total number of genes involved in producing the disease altogether ${ }^{(15)}$.

The heuristic model for BD offers up various assessments to identify endophenotypes, including possible measures of cognitive, neurophysiological, and neuroanatomical changes, images of brain structures, and biochemical measures. This includes environmental data in the model of the disease as possible causes of $B D$, in addition to risk and protection factors ${ }^{(15)}$. Other neuroimaging studies with family members and patients have demonstrated brain abnormalities in bipolar patients, including a reduced size of the prefrontal cortex ${ }^{(17,18)}$.

Some authors have pointed out roles of brain structures such as the nucleus accumbens and amygdala in the regulation of motivation in the sleep-wakefulness cycle, as well as social behaviors in bipolar patients. The anatomy of the hippocampus appears to be impaired in people affected by bipolar disorder ${ }^{(19)}$. There is also a decrease in the volume of the cingulate gyrus according to magnetic resonance imaging $(\mathrm{IMR})^{(20)}$. A set of brain structures (such as the medial temporal lobe, temporal cortex, and frontal cortex) was directly involved in the pathological functioning, and other structures that are no less important but have different functions (the hippocampus, amygdala, and cingulate) would also be modified. Although the reduction in the volume of the anterior cingulate cortex and white matter changes in neuroimaging findings are more consistent and specific in $\mathrm{BD}$, others such as the increased volume of the right lateral ventricle and changes in volume of the amygdala and hippocampus may also be quantified as structural endophenotypes of bipolar disorder ${ }^{(21)}$.

A review article ${ }^{(14)}$ discussed the strategies and the advantages of using the endophenotype model. The model was suggested to be a huge advantage in clinical psychiatry, since the approach would bring possible answers to open questions in the long history of modern psychiatry, particularly psychiatric disorders and bipolar. However, the article stated that further investigation on all models and variables involved in the research of $B D$ is required. These include neuropsychological deficits, instability of circadian rhythms, modulation of motivation, reward circuitry, neuropathological dimorphisms, and response to symptoms. Given the relative scarcity of twin studies, few prospective studies on families evaluating candidate genes for bipolar disorder have been gradually developed with the aim of improving the theoretical model endophenotype ${ }^{(20)}$. Therefore, in the case of mental disorders, a new classification system based on etiology and pathophysiology is necessary. A clearer definition of the endophenotype of $\mathrm{BD}$ will probably facilitate the understanding of the underlying causal structure.

By proposing a phenotypic variance, the endophenotype model that may correspond to different data from the clinical sample identifies and takes into account the aspects of heritability and heredity. Aspects of the personality may be associated with $\mathrm{BD}$, and variation in performance that is observed in patients with mood disorders are useful genetic markers for endophenotypes ${ }^{(22,23)}$. An understanding of the genetic relationships between personality factors and bipolar disorder should elucidate the way in which these traits can develop.

The model of personality that identifies the biological characteristics of the subjects is the Temperament and Character Inventory $(\mathrm{TCl})^{(24)}$. In this model, personality is a dynamic interaction between two complementary elements: temperament, which is structured as a constitutional component, and biological and hereditary character, which consists of experiences acquired through learning and emotional experiences. Temperament is described as the emotional valence of personality and relates to associative learning, perceptual memory, visuo-spatial processing,
Model endophenotype for bipolar disorder: Qualitative Analyse, etiological factors and research areas Tavares NO, Neves FS, Malloy-Diniz LF 
and the formation of habits, involving cortico-striatal projections and a structure-function relationship. The second element is designated as the essence of personality and is related to long-term memories. It involves the formation of concepts and is involved in the cortico-diencephalic-limbico projections ${ }^{(24-26)}$. These dimensions of temperament and character interact, form the individual and their personality, and may indicate bipolar mood disorder ${ }^{(27,28)}$. Thus, individuals with mood disorders seem to have personality traits that are significantly different from the general population. The $\mathrm{TCl}$ demonstrates psychometric features of good reliability, internal consistency, and stability over time ${ }^{(29,30)}$.

\section{Neuropsychology of bipolar disorder}

Neuropsychology evaluates and ranks the relations between cognition and its different functions and processes in the brain structure ${ }^{(31)}$. A review of the subject in order to differentiate the broader and specific cognitive processes indicates that the impairment of cognitive functions in $B D$ is an endophenotype marker. Interest in investigating the cognitive functions of bipolar has been growing, especially in the last decade. This is due to the need to explain whether the cognitive impairments would be traces of the disease or if they occur due to a cognitive impairment, as a neurodegenerative process ${ }^{(31)}$.

In three analyses of the endophenotype of bipolar disorder with patients, unaffected first-degree relatives (fathers, mothers, brothers, twins, and children), and control targets, the endophenotype markers were shown through neuropsychological measures ${ }^{(10,33)}$. However, a meta-analysis claims that these findings should be interpreted with caution, as it is very likely that the confusion of factors such as medication, chronicity, and affective symptoms below the threshold are also contributing to the observed results ${ }^{(34)}$.

The cognitive functions that are affected and have been proven as an endophenotype for BD are sustained attention, verbal memory, and executive functions ${ }^{(35)}$. Studies suggest that some cognitive decline can already be identified after the first episode of $\mathrm{BD}$, which worsens with the number of episodes of the illness ${ }^{(35)}$.

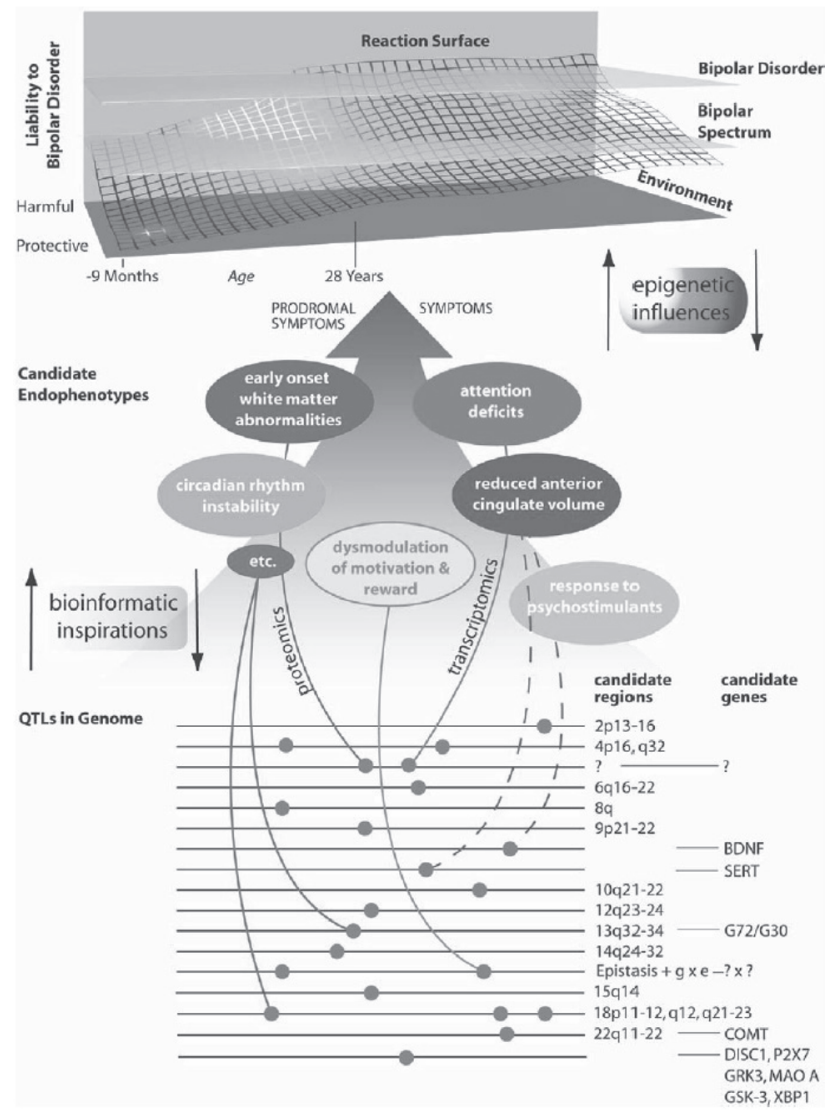

Figure 1 - Heuristic Model of endophenotypes for bipolar mood disorder (adapted from Gotsman, 2003 and modified in Hasler, 2006).

Several authors argue that when crises of bipolar mood disorder are acute, beyond the cognitive loss, there are implications for the quality of sleep and general functionality health ${ }^{(36)}$. Therefore, bipolar disorder is a degenerative process and is directly related to the amount and severity of crises, demonstrating a decline in cognitive subjects with bipolar disorder ${ }^{(37)}$.

From results on the general intelligence factor of patients with $\mathrm{BD}$, small changes could be observed depending on the mood state ${ }^{(31)}$. Surveys report that individuals in the manic phase have greater difficulty in processing visuospatial information and verbal fluency ${ }^{(33)}$. There is a clear potential for losses due to the level of disorganization of behavior and acceleration of mental activity, especially in the presence of psychotic symptoms ${ }^{(37)}$. Thus, manic patients may also present greater difficulties in sustaining attention, recognizing faces, and encoding information ${ }^{(32)}$.

It is known that during a depressive episode, patients show cognitive deficits in multiple domains. Such deficits have been observed in memory, verbal and nonverbal learning, selective attention and sustained attention, reaction time, and executive functions ${ }^{(32)}$. Some authors claim that deficits in executive 
functions are an endophenotype of $\mathrm{BD}^{(33)}$. In this sense, they would present both as a feature of clinical manifestations and a feature of neurodevelopment, meaning that they would be present even before the emergence of $\mathrm{BD}^{(32)}$. In the period of euthymia, cognitive impairments are also observed in sustained attention ${ }^{(37)}$, declarative memory ${ }^{(35)}$, verbal memory ${ }^{(31)}$, the recognition of facial expressions ${ }^{(32)}$, the capacity for learning ${ }^{(35)}$, difficulties in recovery ${ }^{(32)}$, and the organization of information $^{(10)}$. The scientific literature indicates significant differences in several cognitive domains between bipolar patients and controls and unaffected first-degree relatives. The most cited cognitive functions in meta-analysis include the following functions: verbal fluency, problem solving, planning, and divided attention ${ }^{(37)}$.

\section{METHOD}

\section{a) Selection of databases and research documents}

Unique articles in the PubMed/Medline databases were identified and selected by means of word association as follows: bipolar endophenotype(s). The access and retrieval of documents formed a profile of research on endophenotypes and bipolar disorder. Among the results of these 290 specific items with descriptors, we considered only those contained in the full text, with the number of articles being 275 . The terms were extracted from the Medical Subject Heading (MeSH) thesaurus of PMC (Pub Med Central), and the synonyms and derivatives were considered to recover any grammatical variants as well as the terms of the semantic family that have the same root. Table 1 shows the full list of terms found.

Table 1 - List of terms that characterize the model of endophenotypes

List the terms of the documents on

\begin{tabular}{|c|c|c|}
\hline \multirow[t]{2}{*}{ Descriptors } & \multicolumn{2}{|c|}{ endophenotype and bipolar mood disorder } \\
\hline & English & Portuguese \\
\hline Endophenotypes & $\begin{array}{l}\text { Endophenotype; } \\
\text { phenotype; biological } \\
\text { markers; genetic } \\
\text { phenomena; } \\
\text { endophenotypes; } \\
\text { polymorphism genetic }\end{array}$ & $\begin{array}{l}\text { Endofenótipo, fenótipo, } \\
\text { marcadores biológicos; } \\
\text { fenomêno genético; } \\
\text { endofenótipos, } \\
\text { polimorfismo genético }\end{array}$ \\
\hline $\begin{array}{l}\text { Bipolar } \\
\text { Disorders (BD) }\end{array}$ & $\begin{array}{l}\text { Bipolar Disorder(s); } \\
\text { Psychosis(es) Manic (-) } \\
\text { Depressive; } \\
\text { Psychosis Affective; } \\
\text { Psychosis Bipolar; } \\
\text { Bipolar Affective } \\
\text { Psychosis; Psychoses, } \\
\text { Bipolar Affective ; } \\
\text { Psychosis, Bipolar } \\
\text { Affective; Mania; } \\
\text { Manias; Manic State(s) } \\
\text { Bipolar; Bipolar } \\
\text { Depression; Manic } \\
\text { Disorder(s) }\end{array}$ & $\begin{array}{l}\text { Transtorno Bipolar; } \\
\text { Psicose Maníaco- } \\
\text { depressiva; } \\
\text { Psicose Afetiva; } \\
\text { Psicose(s) Bipolar(es) } \\
\text { Afetiva(s); } \\
\text { Mania; } \\
\text { Estado Maníaco- } \\
\text { depressivo; } \\
\text { Estado(s) maníaco(s) } \\
\text { bipolar; } \\
\text { Depressão bipolar; } \\
\text { Transtorno Bipolar do } \\
\text { humor; } \\
\text { Transtorno maníaco }\end{array}$ \\
\hline
\end{tabular}

The surveys were adapted to the idiomatic patterns and opportunities for information retrieval from databases. Only texts with the following documentary typology were used: original research articles, clinical notes, and reviews of literature in the period of 1992-2014. A manual review of documents was conducted concerning the titles, descriptors, keywords, and abstracts. Only empirical articles items were separated, resulting in 37 articles.

\section{b) Selection of documents, standardization, and institutional collaboration networks}

We believe that the references of selected articles were not used as a source, and since we only examined articles written in English, we removed seven articles in French with elements that characterize the endophenotype model. Likewise, a standardization process was performed by authors, year, criterion of researched sources, bibliographic database, and institutional data. We surveyed institutions, institutes research centers, or hospitals that operate independently, with their own resources, or autonomously with their political scientific, which depends on organizations, universities, ministries, or public agencies.

To characterize the thematic areas, we determined the frequency of occurrence of the descriptors and keywords identified in the documents dealing with bipolar disorder as an endophenotype model. Then, we separated the descriptors by the most constant themes within a larger group. For example, all the articles that had the words, genes, loci, heritability, and heredity were grouped under the subject of genetic polymorphism and genetic vulnerability. By approaching content and qualitative analysis, we have chosen the term polymorphism among others. Networks with the thematic relations between the terms were determined from the frequency of their joint appearance in the documents, as were representations which determine the greater or lesser density of the various thematic groups, and the interrelationship between them.

\section{c) Network Diagramming}

The analysis of the network of keywords, abstracts, and full texts showed relations between contents, which was done with the help of UCINET and Web endnote 6.1 software for the purpose of processing information. To form the network, we used the theory of graphs, in which each item represents a graph, and a set of articles on the same theme is a node (a group) ${ }^{(38)}$. The relations were divided according dichotomy (happens or not), non-oriented/oriented $(\rightarrow)$, strong-weak (thick arrows), and where they were cited. We illustrated the relationship between nodes termed weak when compared occur causality, explanation and effect point out as strong relations between arrays of nodes and the set of lines or adjacent space (Graph 1) The distance between nodes identifies localized themes. 


\section{RESULTS}

In the end, we selected 37 articles with full text and empirical research that identified the model of endophenotypes in patients with bipolar disorder (BD). We formed a set in which nodes and lines arranged in pairs comprised a matrix. By positioning the articles and networks, instutitional collaboration and research themes were identified by the relationships within the endophenotype model. When researching each article that characterizes bipolar disorder endophenotypes, we verified the network described by Figure 1.

The analytic network indicates within research themes that the constructs and etiology of bipolar disorder seem to be more associated with psychological aspects (cognition and personality) than the related environmental aspects, such as stress, and that the biological mechanisms (neuroscience and genetics) complement the network. The current model of biopsychosocial health indicates that no factor alone explains psychiatric illness. In each network node is a blue square, and each digraph is associated by means of a component adjacent to the discussion in the article for the systematic analysis of the collected matrix. The thematic approaches addressed by different authors led to the qualitative analysis and network formation.

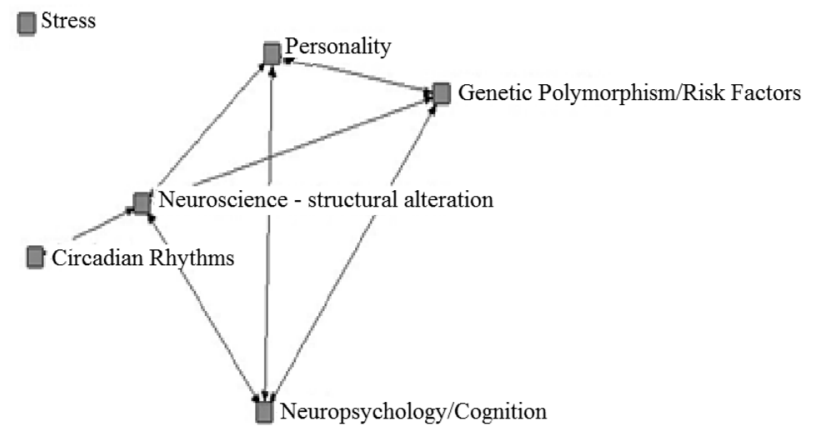

Graph 1- Key relationships between the content of articles that discuss the empirical endophenotype model

\section{DISCUSSION}

In performing the study, we characterized the state of the art on the development of research on the model of endophenotypes as a model of health. It was possible to identify the research groups and the main subjects studied within a proposed group since $1973^{(1,5)}$. This can be verified empirically in the current year model ${ }^{(15)}$.

The following points present the limitations of the study: a) The search for an empirical research profile may be the reason for the non-appearance of relevant articles. b) Although other types of research were on the databases, the agglomeration of themes and models was ultimately limited to journals of Medicine, Biology, and Psychology. Unveiling the contributions of the humanities and social sciences and their epistemological bases on the psychiatric disorder contribute little to the discussion in the empirical context. c) The items that comprised the social network analysis on the subject were work published in scientific journals, excluding other document types such as books and book chapters, oral presentations, reports, dissertations, or doctoral theses. d) Only articles in English were used due to a lack of indexing or to the low impact factor of journals in French, Japanese, or Scandinavan $^{(16)}$. However, one can point out that the methodology applied is the most appropriate in relation to the purpose of the study, since it allows for the recovery of the works of an area of knowledge characterized by a large dispersion among various journals and disciplines ${ }^{(11)}$ in order to minimize the non-retrieval of relevant documents. Therefore, it appears that scientific articles are the most frequent document type, with bigger and better impact. Thus, using only research journals gives validity to the approach performed ${ }^{(38)}$. This also verifies the character of qualitative research ${ }^{(32)}$.

Compared with the analysis of institutional typologies that the funding models for healthcare will prioritize intervention continues as a form of research, i.e. the analysis of themes found dealing research through magazines are produced by organisms relevant administrative and clinical nature. Mostly, research points at generated devices of public and political services (consortia or collaborative networks for genetic mapping, observatories, and research partnerships) and health (hospitals, health centers, clinics linked to public, private hospitals or psychiatric services bound to universities and research centers), which comprise 70 percent of the institutions. Although there is an interrelationship between the signs and symptoms of the pathology of bipolar mood disorder (BD) is most common. When research resemble those disciplines stand out in this study Biology, Psychiatry, Genetics, Psychology, Public Health and Epidemiology, though medical specialty magazines on the subject (such as Journal of Affective Disorders - Journal of Affective Disorders and bipolar disorder - Bipolar Disorders) most work on bipolar disorder and endophenotypes, the which tends to confirm the multidisciplinary character of the area, about the approach of endophenotypes models with empirical data is small compared to other models of qualitative or quantitative research, described here as an administrative medical and psychological character. On the other hand, international publications include a greater measure of character of basic research involving large workgroups, with a greater weight of collaborative research between different areas of knowledge and studies released by leading universities and research centers. 
Based on observations found in the various themes, it becomes desirable to foster the causal inter-relation among all types of research mentioned, favoring communication between different levels ${ }^{(12)}$. The aim is to reduce the watertight increase the level of relationship between the themes, since all types of research are fundamental to the advancement of knowledge and professional practice. Therefore, the use of social network analysis to highlight what is being researched in psychiatric pathology shows the importance of these inter-relationships, and we deduce that they are also works of interest and usefulness to the scientific community.

\section{CONCLUSION}

Bipolar mood disorder (BD) has been studied by several researchers at different times and in different areas of knowledge. The search for common characteristics in people without the condition led us to the concept of endophenotype. The search for endophenotypes of BD arises from a number of etiological disease characteristics. When starting the theoretical literature review, we saw the dominance of nosographical characteristics, which are relevant. However, because it is such a complex process, the possible causes could be covert (genetic vulnerabil-

\section{REFERENCES}

1. Gottesman II, Shields J. Genetic Theorizing and schizophrenia. Br J Psychiatry.1973; (122): 15-30.

2. Goodwin FK, Jamison KR. Manic-Depressive Illness: Bipolar Disorders and Recurrent Depression [monograph online]. 2nd ed. New York: Oxford University Press, 1990.

3. Barondes SH. Mood Genes: Hunting for Origins of Mania and Depression [monograph online]. 1 st ed. Oxford: Oxford University Press, 2002.

4. Smoller JW, Finn CT. Family, Twin, and Adoption Studies of Bipolar Disorder. American Journal of Medical Genetics. [Internet]. 2003[cited 2014 jan. 18]; 123C (1), 48-58 I Part C (Semin. Med. Genet) Avaliable from: http://onlinelibrary.wiley.com/ doi/10.1002/ajmg.c. 20013/abstract;jsessionid=1859C0E189D 138C75CE0084F8B3F8C53.f04t04?deniedAccessCustomised Message $=$ \&userlsAuthenticated $=$ false .

5. Gottesman II, Shields J. A polygenic theory of schizophrenia. Proc Natl Acad Sci, 1967; (58):199 -205.

6. McGue M, Gottesman II, Rao DC. The transmission of bipolar disorders under a multifactorial threshold model. Am J Hum Genet [Internet] . 1983 [cited 2014 feb.4]; 35(6):1161-1178. Avaliable from: http://www.ncbi.nlm.nih.gov/pmc/articles/ PMC1685995/ ity, stressors, changes in the circadian cycle, changes in neurotransmitters, cognitive deficits), because there is no single intermediate phenotype.

In this context, it is important to consider the individual, the environment, and first-degree relatives. How might the implications of the study be questioned: What are the risks of a healthy person in an environment that causes them stress or trauma to develop a pathology. Are there changes or markers that could trigger the disease. Risk factors for the development of psychiatric disorders are still largely unknown. The influence of the endophenotype has been recognized, and studies are seeking potential biomarkers. The identification of such markers could shed light on the discussion about developing the disorder. In addition to compiling data for diagnostic manuals, risk factors could help predict and understand bipolar disorder and bring the concept.

\section{ACKNOWLEDGEMENTS}

Support for the study was provided the University of Goiás (UFG) and the University of Minas Gerais (UFMG). E DFBR (Deleted for Blind Review).
7. Manji HK and Duman RS. Impairments of neuroplasticity and cellular resilience in severe mood disorders: Implications for the development of novel therapeutics. Psychopharmacol Bull. [Internet]. 2001 [cited 2014 mar 15]; 35(2):4549. Avaliable from: http://www.ncbi.nlm.nih.gov/pub$\underline{\text { med/12397885 }}$

8. Mandelli L, Serretti A, Marino E. Interaction between serotonin transporter gene, catechol-O-methyltransferase gene and stressful life events in mood disorders. Int J Neuropsychopharmacol.. [Internet]. 2007 [cited 2014 mar 15]; 10(4): 437-447. Avaliable from: http://journals-cambridge-org.ez27.periodicos.capes.gov.br/action/displayAbstract?fromPage=online\&a $\underline{i d=1051056}$

9. Nestler EJ, Barrot M, Di Leone RJ, Eisch AJ, Gold SJ, Monteggia LM. Neurobiology of depression. Neuron [Internet]. 2002 [cited 2014 apr. 2014]; 34(1), 13-25. Avaliable from: http:// www.ncbi.nlm.nih.gov/pubmed/11931738

10. Frangou S, Haldane M, Roddy M, Kumari V. Evidence for deficits in tasks of ventral, but not dorsal, prefrontal executive function as an endophenotypic marker for bipolar disorder. Biol. Psychiatry. [Internet]. 2005 [cited 2014 feb.28]; 58(10), 838-839. Avaliable from: http://www-sciencedirectom.ez27.periodicos.capes.gov.br/science/article/pii/ s0006322305006165
Model endophenotype for bipolar disorder: Qualitative Analyse, etiological factors and research areas Tavares NO, Neves FS, Malloy-Diniz LF 
11. Öngür D, Drevets WC, Price JL. Glial reduction in the subgenual prefrontal cortex in mood disorders. Proc Natl Acad Sci U S A. [Internet].1998 [cited 2014 mar. 10]; 95(22), 13290-13295 .Avaliable from: http://ww.pnas.org/content/95/22/13290.full.

12. Benedetti F, Serretti A, Colombo C, Lorenzi C, Tubazio V, Smeraldi E. A glycogen synthase kinase 3-beta promoter gene single nucleotide polymorphism is associated with age at onset and response to total sleep deprivation in bipolar depression. Neurosci Lett. [Internet] 2004. [cited 2014 mar.13]; 368(2),123-126. Avaliable from: http://www.ncbi.nlm.nih.gov/pubmed/15351432

13. Jones SJ, Hare DJ, Evershed K. Actigraphic assessment of circadian activity and sleep patterns in bipolar disorder. Bipolar Disord. [Internet] 2005. [cited 2014 mar.13]; 7(2), 176-186. Avaliable from: http://www.ncbi.nlm.nih.gov/ pubmed/15762859

14. Hasler G, Drevets WC, Gould TD, Gottesman II, Manji KH. Toward Constructing an Endophenotype Strategy for Bipolar Disorders. Biological Psychiatry . [Internet] 2006. [cited 2014 mar.20]; 60(2), 93-105. Avaliable from: http://www.ncbi. nlm.nih.gov/pubmed/16406007

15. Gottesman II and Gould TD. The endophenotype concept in psychiatry: etymology and strategic intentions. Am. J. Psychiatr. [Internet] 2003.[cited 2014 mar.13]; 160 (4), 636645. Avaliable from: http://journals.psychiatryonline.org/ article.aspx?articleid $=176146$

16. Bora E, Yucel M, Pantelis C. Cognitive endophenotypes of bipolar disorder: A meta-analysis of neuropsychological deficits in euthymic patients and their first-degree relatives. Journal of Affective Disorder. [Internet] 2009. [cited 2014 mar.13]; 113(1), 1-20. Avaliable from: $\quad$ http://www-sciencedirect-com.ez27.periodicos.capes.gov.br/science/ article/pii/S0165032708002462

17. Glahn DG, Bearden DE, Niendam TA, Escamilla MA. The feasibility of neuropsychological endophenotypes in the search for genes associated with bipolar affective disorder. Bipolar Disord. [Internet] 2004.[cited 2014 mar.13];6 (3), 171-182. Avaliable from: http://www.ncbi.nlm.nih.gov/ pubmed/15117396

18. Hall H, Schulze K, Rijsdijk F, Kalidindi S, McDonald C, Bramon E, Murray RM, Sham P. Are auditory P300 and duration MMN heritable and putative endophenotypes of psychotic bipolar disorder? A Maudsley bipolar twin and family study. Psychol Med. [Internet] 2009.[cited 2014 mar.13]; 39 (8),1-11. "In press".

19. Pezawas L, Meyer-Lindenberg A, Drabant EM, Verchinski BA, Munoz KE, Kolachana BS. 5-HTTLPR polymorphism impacts human cingulate-amygdala interactions: A genetic susceptibility mechanism for depression. Nat Neurosci. [Internet] 2005. [cited 2014 mar.13]; 8 (6), 828-834. Avaliable from: http:// www.nature.com/neuro/journal/v8/n6/abs/nn1463.html
20. Hirayasu Y, Shenton ME, Salisbury DF, Kwon JS, Wible CG, Fischer IA. Subgenual cingulate cortex volume in first-episode psychosis. Am J Psychiatry. [Internet]. 1999.[cited 2014 mar.13]; 156 (7), 1091-1093. Avaliable from: http://journals. psychiatryonline.org/article. aspx?articleid $=173577$

21. McDonald C, Bullmore ET, Sham PC, Chitnis X, Wickham H, Bramon E. Association of genetic risks for schizophrenia and bipolar disorder with specific and generic brain structural endophenotypes. Archives of general psychiatry. [Internet] 2004.[cited 2014 mar.13]; 61(10), 974-84. Avaliable from: http://archpsyc.jamanetwork.com/article. aspx?articleid $=482068$

22. Lara DR, Akiskal HS. Toward an integrative model of the spectrum of mood, behavioral and personality disorders based on fear and anger traits: Implications for neurobiology, genetics and psychopharmacological treatment. Journal of Affective Disorders. [Internet] 2006. [cited 2014 mar.13];94(1-3), 89-103. Avaliable from: http://www. sciencedirect.com/science/article/pii/S0165032706001303

23. Savitz JB, Ramesar, RS. Personality: is it a viable endophenotype for genetic studies of bipolar affective disorder? Bipolar Disord. [Internet] 2006.[cited 2014 mar.13]; 8(4), 322-37. Avaliable from: http://onlinelibrary.wiley.com/doi/10.1111/ j.1399-5618.2006.00309.x/abstract?deniedAccessCustomis edMessage $=\&$ userlsAuthenticated $=$ false

24. Cloninger CR, Svrakic DM, Pryzbeck TR. A psychobiological model of temperament and character. Arch Gen Psychiatry. [Internet]. 1993 .[cited 2014 mar.13];50(12),975-990. Avaliable from: http://archpsyc.jamanetwork.com/article. aspx?articleid $=496431$

25. Savitz J, Van der Merwe L, Ramesar R. Hypomanic, cyclothymic and hostile personality traits in bipolar spectrum illness: a family-based study. Psychiatr Res. [Internet] 2008.[cited 2014 mar.13];42(11),920-929.Avaliable from: http://www-sciencedirect-com.ez27.periodicos.capes.gov.br/science/ article/pii/S0022395607001823

26. Greenwood TA, Badnerb JA, Byerleyc W, Kecke PE, McElroye SL, Remickg RA, Sadovnickh D, Kelsoea JR. Heritability and linkage analysis of personality in bipolar disorder. Journal of Affective Disorders. [Internet] 2013. [cited 2014 mar.13];151(2), 748-755. Avaliable from:

http://dx.doi.org.ez27.periodicos.capes.gov.br/10.1016/i. jad.2013.06.015

27. Harley JA, Wells JE, Frampton CM, Joyce PR. Bipolar disorder and the $\mathrm{TCl}$ : higher self-transcendence in bipolar disorder compared to major depression. Depression Research and Treatment. [Internet] 2011.[cited 2014 mar.13]; (yr:2011 vol:2011), 529-638. Avaliable from: http://www.hindawi. com/journals/drt/2011/529638/ 
28. Loftus ST, Garno JL, Jaeger J, Malhotra AK. Temperament and character dimensions in bipolar I disorder: a comparison to healthy controls. Journal of Psychiatric Research. [Internet] 2008 .[cited 2014 mar.13];42(13),1131-1136. Avaliable from: http://www.sciencedirect.com/science/article/ pii/S0022395607001926

29. Cloninger CR, Przybeck TR, Svrakic DM, Wetzel RD. The Temperament and Character Inventory (TCl): A Guide to its Development and Use, Center for Psychobiology of Personality. Center of Psychobyology of personality, Washington University: St. Louis, MO, 1993.

30. Keller MC, Coventry WL, Heath AC, Martin NG. Widespread evidence for non-additive genetic variation in Cloninger's and Eysenck's personality dimensions using a twin plus sibling design. Behavior Genetics. [Internet] 2005. [cited 2014 mar.13]; 35 (6), 707-721. Avaliable from: http://link.springer.com/article/10.1007/s10519-005-6041-7\#page-1

31. Lezak MD, Howieson DB, Loring DW. Neuropsychological Assessment. 4th ed. New York: Oxford University Press, 2004.

32. Kapczinski F, Quevedo J (editors). Transtorno Bipolar: teoria e clínica. Porto Alegre: Artmed, 2009.

33. Arts B, Jabben N, Krabbendam L, Van OSJ. Meta-analyses of cognitive functioning in euthymic bipolar patients and their first degree relatives. Psychol Med. [Internet].2008 .[cited 2014 mar.13];38 (6), 771-785. Avaliable from: http://www. ncbi.nlm.nih.gov/pubmed/17922938

34. Bora $E$, Yucel M, Pantelis C. Cognitive endophenotypes of bipolar disorder: A meta-analysis of neuropsychological deficits in euthymic patients and their first-degree relatives. Journal of Affective Disorders. [Internet] 2009. [cited 2014 mar.20];113(1), 1-20. Avaliable from: http://www.ncbi.nlm. nih.gov/pubmed/18684514
35. Martínez-Arán A, Vieta E, Colom F, Reinares M, Benabarre A, Gastó C, Salamero M, Cognitive Dysfunctions. Bipolar Disorder: Evidence Of Neuropsychological Disturbances. Psychother Psychosom. [Internet] 2010 .[cited 2014 mar.13];69 (1), 2-18. Avaliable from: http://www.ncbi.nlm.nih.gov/pubmed/10601830

36. Kapczinski, F.; Andreazza, A. C.; Salvador, M. Mediadores do déficit cognitivo e comorbidades clínicas no transtorno bipolar: análise de marcadores periféricos de estresse oxidativo, dano ao DNA e apoptose. Porto Alegre: UFRGS, 2008. Avaliable from: http://200.18.45.28/sites/ppgp/images/documentos/texto\%208.pdf

37. Zalla T. Executive dysfunctions as potential markers of familial vulnerability to bipolar disorder and schizophrenia. Psychiatry Researc. [Internet] 2004.[cited 2014 mar.13]; 21(3), 207-217. Avaliable from: http://www.ncbi.nlm.nih. gov/pubmed/14675740

38. Pirkola T, Tuulio-Henriksson, Glahn AD, Kieseppä T, Haukka J, Kaprio J, Lönnqvist J, Cannon TD. Spatial Working Memory Function in Twins with Schizophrenia and Bipolar Disorder.Biological Psychiatry.[Internet] 2005.[cited 2014 mar.13];58(12),930-936. Avaliable from: http://www.ncbi. nlm.nih.gov/pubmed/16112657

39. Paquali L. Psicometria. Revista da Escola de Enfermagem USP. [Internet] 2008; 43(Esp):992-999. Avaliable from: http://www.scielo.br/scielo.php?pid=S0080$\underline{-62342009000500002 \& \text { script }}$ www.ee.usp.br/reeusp/
Correspondence address to: Naraiana de Oliveira Tavares Rua 235 - setor Universitário CEP 74605-050 - Goiânia, GO, Brazil tavares.naraiana@gmail.com 